\title{
Pathological personality and quality of life: Validity evidences for IDCP-2
}

\author{
Lucas de Francisco Carvalho ${ }^{1}$ \\ Dttps://orcid.org/0000-0002-3274-9724 \\ Ana Carolina Zuanazzi ${ }^{1}$ \\ iD https://orcid.org/0000-0003-1649-2372 \\ Fabiano K. Miguel $^{2}$ \\ iD https://orcid.org/0000-0003-2498-692X
}

To cite this paper: Carvalho, L. F., Zuanazzi, A. C., \& Miguel, F. K. (2019). Pathological personality and quality of life: Validity evidences for IDCP-2. Psicologia: Teoria e Prática, 21(2), 21-40. doi:10.5935/1980-6906/psicologia.v21n2p21-40

Submission: $23 / 10 / 2017$

Acceptance: $15 / 04 / 2019$

(cc)BY

The content of Psicologia: Teoria e Prática is distributed under the terms of the Creative Commons Attribution License.

1 University of São Francisco (USF), SP, Brazil.

2 State University of Londrina (UEL), PR, Brazil. 


\begin{abstract}
This study aimed to investigate validity based on external criteria, i.e., the quality of life, of the Dimensional Clinical Personality Inventory 2 (IDCP-2), an instrument that assesses pathological personality traits. 1618 Brazilians answered IDCP-2, WHOQOLbref, PANAS, and Life Satisfaction scale. The results indicated negative correlations between specific domains of IDCP-2 and life satisfaction and experience of positive affects. Regression analysis using IDCP-2 domains as independent variables and scores from PANAS, life satisfaction, WHOQOL, and clinical sociodemographic variable as dependent variables showed predictive capacity from .27 (life satisfaction) to .48 (general life quality). Our findings indicate that IDCP-2 could be used as an indicator of the absence or the lack of positive outcomes presently investigated. Mostly, we found that presenting high scores on Self-sacrifice and Isolation and low scores on Conscientiousness is indicative of the poor quality of life.

Keywords: quality of life; personality; personality disorders; psychological testing; personality assessment.
\end{abstract}

\title{
PERSONALIDADE PATOLÓGICA E QUALIDADE DE VIDA: EVIDÊNCIAS DE VALIDADE PARA O IDCP-2
}

\section{Resumo}

O objetivo deste estudo foi buscar evidências de validade com base em critérios externos (qualidade de vida) para o Inventário Dimensional Clínico da Personalidade 2 (IDCP-2). Participaram do estudo 1.618 brasileiros, que responderam ao IDCP-2, ao WHOQOL-bref, à PANAS e à Escala de Satisfação de Vida. Encontramos correlações negativas entre fatores específicos do IDCP-2 e satisfação com a vida e experiência de afetos positivos. A análise de regressão com dimensões do IDCP-2 como preditores e os escores na PANAS, satisfação com a vida, WHOQOL e variável clínica-demográfica como variáveis dependentes demonstrou capacidade preditiva entre 0,27 (satisfação com a vida) e 0,48 (qualidade de vida geral). Os resultados sugerem que o IDCP-2 pode ser utilizado como indicador da falta ou o rebaixamento quanto aos desfechos positivos presentemente estudados. No geral, encontramos que altas pontuações em Autossacrifício e Isolamento e baixos escores em Conscienciosidade são indicativos de baixa qualidade de vida.

Palavras-chave: qualidade de vida; personalidade; transtornos da personalidade; testagem psicológica; avaliação da personalidade. 


\section{PERSONALIDAD PATOLÓGICA Y CALIDAD DE VIDA: EVIDENCIAS DE VALIDEZ PARA EL IDCP-2}

\section{Resumen}

Este estudio tuvo como objetivo investigar validez del Inventario de Personalidad Clínica Dimensional 2 (IDCP-2) a partir de criterios externos (calidad de vida). 1618 brasileños contestaron IDCP-2, WHOQOL-bref, PANAS y escala de Satisfacción de Vida. Los resultados indicaron correlaciones negativas entre factores específicos del IDCP-2 y aspectos de la calidad de vida, y experiencia de afectos positivos. El análisis de regresión utilizando dominios IDCP-2 como variables independientes y puntuaciones de PANAS, satisfacción con la vida, WHOQOL y variables socio demográficas clínicas como variables dependientes mostró una capacidad predictiva de .27 (satisfacción con la vida) a .48 (calidad de vida general). Nuestros hallazgos sugieren que el IDCP-2 podría usarse como un indicador de la ausencia o la falta de los resultados positivos investigados actualmente. Encontramos que la presentación de puntuaciones altas en el sacrificio y el aislamiento y puntuaciones bajas en la conciencia es un indicio de la calidad de vida deficiente.

Palabras clave: calidad de vida; personalidad; desorden de personalidad; pruebas psicológicas; evaluación de la personalidad.

\section{Introduction}

Pathological traits of personality indicate a tendency for the person to present shortcomings and impairments regarding one's self and interpersonal relations (American Psychiatric Association [APA], 2013; Millon, 2011). Individuals with high levels of pathological personality traits, which may constitute a personality disorder, also tend to show a decrease in several global indicators of health and quality of life (Kotov et al., 2017). These impairments can affect the way people think and see the world, their relationships, and the way they experience life. In other words, there is a relation between pathological patterns of personality and the worst experience of positive and negative affects, and lesser life satisfaction (Cloninger \& Zohar, 2011; Farrand \& Woodford, 2013; Manning, 2000; Narud, Mykletun, \& Dahl, 2005).

Findings indicate that the influence of personality disorders is more significant as a predictor of quality of life than sociodemographic or health condition variables, for example (Brunault et al., 2016; Cramer, Torgersen, \& Kringlen, 2006). The concept of quality of life summarizes the degrees of satisfaction in several 
domains of life, such as work, family, health, among others (Brief, Butcher, George, \& Link, 1993; Karimi \& Brazier, 2016; Wilson, 1967). Therefore, quality of life involves the way people experience positive and negative affects in several contexts and their level of satisfaction with conditions presented, which is considered an indicator of health and wellbeing. Because of such a broad definition, measurement of quality of life can refer to a more extensive, unidimensional perspective, such as the individual's perceptions towards life in general, or specific, multidimensional perspective, such as satisfaction with social interactions, with physical health, among others, with measurement scales focusing on either perspective (Acquadro, Conway, Hareendran, \& Aaronson, 2008; Cella, 1994; Farquhar, 1995; Felce \& Perry, 1995; Fleck et al., 2000).

In a systematic review conducted by Huang et al. (2017), the researchers investigated the relationship between health-related quality of life and personality traits. The results indicated that personality traits such as neuroticism and negative affectivity were related to poorer quality of life, while extraversion and conscientiousness were related to greater perception of quality of life. Also, the authors concluded that personality characteristics have indirect and moderating effects on different domains of quality of life. This influence is greater in psychosocial aspects than physical aspects.

Anderson and Sellbom (2016) evaluated the relations of quality of life with personality disorders in 277 undergraduate students without previous diagnoses. All the personality disorders assessed (antisocial personality disorder, avoidant personality disorder, borderline personality disorder, narcissistic personality disorder, obsessive-compulsive personality disorder, and schizotypal personality disorder) correlated negatively with the perception of the quality of life, indicating the extent of impairment to the individual well-being.

Therefore, measures that assess pathological personality traits are expected to be able to discriminate between people with high and low scores on these global indicators. In the present study, we tested the discriminative capacity of the Dimensional Clinical Personality Inventory 2 (IDCP-2; Carvalho \& Primi, 2018), investigating its validity based on external criteria. Specifically, the criteria we used were related to the quality of life, including experiences of positive and negative affects, and life satisfaction. We expected negative and moderate correlations between pathological patterns of personality and life satisfaction, positive 
experience of affects, and quality of life. In addition, we expected positive and moderate correlations between pathological patterns of personality and experience of negative affects.

\section{Method}

\subsection{Participants}

The participants of this research were 1618 Brazilian people, being $65.7 \%$ women, with ages varying from 18 to $70(M=27.7 ; S D=9.55)$. Regarding schooling, $1.4 \%$ had primary school level, $26.3 \%$ had high school level, $56.9 \%$ had undergraduate level, and $15.4 \%$ had graduate level.

\subsection{Measures}

\subsubsection{WHOQOL-bref}

This 26-item instrument assesses the perception of the quality of life through four domains: physical health, psychological health, social relationships, and environment. The WHOQOL-bref is the short version of the WHOQOL-100, developed by the World Health Organization (The WHOQOL Group, 1998). It is possible to calculate a total score by summing all four domains, but in this research, we only used the domains because they are context-specific. The participant responds to each item in a Likert scale ranging from 1 ("very poor") to 5 ("very good"). The test reliability of the Brazilian version indicated Cronbach's alphas varying from .69 (environment domain) to .84 (physical health domain) (Fleck et al., 2000). For our sample, Cronbach's alpha was .77 for physical health, .80 for psychological health, .65 for social relationships, and .77 for environment.

\subsubsection{Positive and Negative Affect Schedule (PANAS)}

PANAS is a self-report inventory that lists ten positive affects and 10 negative affects, to which the participants answer in a Likert scale the level they have been feeling lately, from 1 ("very slightly or not at all") to 5 ("extremely") (Watson, Clark, \& Tellegen, 1988). There are two scores, which are calculated by summing the individual scores for the 10 positive affects and for the 10 negative affects, with a minimum of 10 and maximum of 50 for each. For this research, we used the Brazilian version developed Giacomoni and Hutz (1997). For our sample, the Cronba- 
ch's alpha was .80 for the positive affects scale, and .87 for the negative affects scale.

\subsubsection{Life Satisfaction}

The brief scale contains five phrases that the participants score in a Likert-type scale from 1 ("strongly disagree") to 7 ("strongly agree"), indicating general satisfaction with life, such as life conditions and achieving goals in life. The scale was originally developed by Diener, Emmons, Larsen, and Griffin (1985), and it produces a final score by summing the scores given for the five items, with a minimum of 5 and maximum of 35. The scale was adapted to Brazilian participants by Zanon, Bardagi, Layous, and Hutz (2014). For our sample, the Cronbach's alpha was .85.

\subsubsection{Dimensional Clinical Personality Inventory 2}

This self-report inventory for adults, developed in Brazil, was originally based on Millon's personality theory and axis II from DSM-IV (Carvalho \& Primi, 2015), and was aimed to be used for clinical purposes. In our research, we use a revised version, the IDCP-2 (Carvalho \& Primi, 2018), which is composed by 206 items that the participant answers in a Likert-type scale in a range from 1 ("nothing, it has nothing to do with me") to 4 ("very, it has a lot to do with me"). There are 47 factors representing 12 dimensions (Dependency, Aggressiveness, Mood Instability, Eccentricity, Attention Seeking, Distrust, Grandiosity, Isolation, Criticism Avoidance, Self-sacrifice, Conscientiousness, and Inconsequence). Only two items are shared between dimensions, i.e., one item is both in Attention Seeking and Grandiosity dimensions, respecting the manipulation trait, and one item is both in Eccentricity and Criticism Avoidance, related to preference for being alone.

In addition, there are six clinical questions at the end of the IDCP-2, to which the participant answers "Yes" or "No". These questions are related to existence of psychiatric diagnosis, participation in therapy (psychological or psychiatric), and experience of suicidal thoughts. For our sample, the Cronbach's alphas of the domains varied from .83 to .91. Previous studies (Carvalho \& Sette, 2017; Carvalho \& Silva, 2016) showed coherent correlations between IDCP-2 dimensions and factors with Personality Inventory for DSM-5 (Krueger, Derringer, Markon, Watson, \& Skodol, 2012). 


\subsection{Procedures}

The research was approved by the Committee of Ethics in Research of the State University of Londrina. People were invited to participate via social networks. All administration happened online. The participants were first shown the Free Consent Term. The term was accepted by clicking the acceptance button, which then (and only then) showed the instruments to be answered. Half of the sample answered IDCP-2 first, and then the quality of life instruments in the following order: WHOQOL, PANAS, and Life Satisfaction. The other half of the sample answered first the quality of life instruments in the same order, and then the IDCP- 2 .

\subsection{Data Analysis}

To verify the magnitudes of association between pathological personality traits and quality of life, we used Pearson correlations between IDCP-2 domains and the other measures (WHOQOL, PANAS, and Life Satisfaction). To further understand the results, in the cases in which it was appropriated and needed, we calculated correlations between IDCP-2 factors and the life quality measures, as it helped to understand the correlations with the IDCP-2 dimensions better. We supplemented the effect size cutoff for correlations with power analysis in G*Power 3.1. For that, we inputted power $\geq .80, N=275, p \leq .05$, finding an expressive effect size starting from .17. We also used Hemphill20 for interpretation purposes.

To understand how personality traits relate to life quality better, we conducted logistic and multiple regressions, depending on the variables to be predicted, using Wald forward method, with IDCP-2 scores as independent variables, aiming to predict life quality measures. We also controlled for gender and age. Four dependent variables were studied separately: score of positive affect from PANAS; score of life satisfaction; total score of WHOQOL (i.e., the sum of all four scales); and a variable called clinical sociodemographic related to the six clinical questions at the end of IDCP-2 (in this case, the logistic regression was used). The clinical sociodemographic variable was scored zero for participants that answered "No" to all questions, and one for participants that answered "Yes" to at least one question. We also generated graphs to help visualize the results. For that, we dichotomized the other three variables (i.e., positive PANAS, life satisfaction, and WHOQOL), scoring zero for the lower quartile and one for the upper quartile. 


\section{Results}

Initially we correlated the IDCP-2 dimensions with the quality of life measures (WHOQOL, PANAS and Life Satisfaction). The results are in Table 3.1.

Table 3.1. Correlations between measures of quality of life and IDCP-2 domains $(\mathrm{N}=1618)$.

\begin{tabular}{|c|c|c|c|c|c|c|c|}
\hline & $\begin{array}{l}\text { WHOQOL } \\
\text { Physical }\end{array}$ & $\begin{array}{l}\text { WHOQOL } \\
\text { Psycholo- } \\
\text { gical }\end{array}$ & $\begin{array}{c}\text { WHOQOL } \\
\text { Social }\end{array}$ & $\begin{array}{l}\text { WHOQOL } \\
\text { Ambient }\end{array}$ & PANAS+ & PANAS- & $\begin{array}{c}\text { Life } \\
\text { Satisfaction }\end{array}$ \\
\hline Dependency & $-.39 * *$ & $-.58 * *$ & $-.39 * *$ & $-.30 * *$ & $-.44^{* *}$ & $.58 * *$ & $-.41 * *$ \\
\hline Aggressiveness & $-.20 * *$ & $-.25 * *$ & $-.22 * *$ & $-.15^{* *}$ & -.05 & $.25^{* *}$ & $-.20 * *$ \\
\hline Eccentricity & $-.30 * *$ & $-.34^{* *}$ & $-.35^{* *}$ & $-.24^{* *}$ & $-.22 * *$ & $.34^{* *}$ & $-.26 * *$ \\
\hline Attention Seeking & $-.13 * *$ & $-.11 * *$ & -.05 & -.06 & $.09 *$ & $.19^{* *}$ & -.066 \\
\hline Distrust & $-.25^{* *}$ & $-.35^{* *}$ & $-.36 * *$ & $-.24^{* *}$ & $-.12 * *$ & $.31^{* *}$ & $-.23^{* *}$ \\
\hline Criticism Avoidance & $-.41^{* *}$ & $-.58 * *$ & $-.45^{* *}$ & $-.39 * *$ & $-.46 * *$ & $.54^{* *}$ & $-.38 * *$ \\
\hline Self-sacrifice & $-.42 * *$ & $-.63 * *$ & $-.42^{* *}$ & $-.36 * *$ & $-.43^{* *}$ & $.62 * *$ & $-.50 * *$ \\
\hline Conscientiousness & $-.14^{* *}$ & $-.21^{* *}$ & $-.24^{* *}$ & $-.16 * *$ & -.07 & $.24^{* *}$ & $-.14^{* *}$ \\
\hline Inconsequence & $-.13 * *$ & $-.14^{* *}$ & $-.13 * *$ & $-.08 *$ & -.01 & $.14^{* *}$ & $-.15 * *$ \\
\hline
\end{tabular}

Note: Effect size expressive from .17 (using power $\geq .80, N=275, \mathrm{p} \leq .05$ ), calculated in G*Power 3 and based on Hemphill (2003).

$* \mathrm{p}<=.05, * * \mathrm{p}<=.01$

Most of the IDCP-2 domains displayed significant and expressive correlation with the other measures (i.e., WHOQL, PANAS, and Life Satisfaction). Almost all correlations were significant. A few domains displayed only low (or few moderate) correlations with life quality, namely, Attention Seeking, Grandiosity, Inconsequence, and Conscientiousness. Higher correlation was between Mood Instability and WHOQOL psychological domain (negative) and PANAS- (positive); the lowest significant (negative) correlation was between Grandiosity and WHOQOL physical domain and Inconsequence and WHOQOL ambient domain. To understand the relation (or lack of it) between these domains and quality of life better, we ran correlation analyses with their factors. The results are shown in Table 3.2. 
Table 3.2. Correlations between measures of quality of life and specific IDCP-2 factors $(N=1618)$.

\begin{tabular}{|c|c|c|c|c|c|c|c|}
\hline & $\begin{array}{l}\text { WHOQOL } \\
\text { Physical }\end{array}$ & $\begin{array}{l}\text { WHOQOL } \\
\text { Psycholo- } \\
\text { gical }\end{array}$ & $\begin{array}{l}\text { WHOQOL } \\
\text { Social }\end{array}$ & $\begin{array}{l}\text { WHOQOL } \\
\text { Ambient }\end{array}$ & PANAS+ & PANAS- & $\begin{array}{c}\text { Life } \\
\text { Satis- } \\
\text { faction }\end{array}$ \\
\hline \multicolumn{8}{|l|}{$\begin{array}{l}\text { IDCP-2 - } \\
\text { Attention } \\
\text { Seeking }\end{array}$} \\
\hline $\begin{array}{l}\text { Seduction } \\
\text { and } \\
\text { Manipulation }\end{array}$ & .02 & $.16 * *$ & $.11^{* *}$ & $.09 * *$ & $.25^{* *}$ & -.07 & $.12 * *$ \\
\hline $\begin{array}{l}\text { Emotional } \\
\text { Intensity }\end{array}$ & $-.27^{* *}$ & $-.34^{* *}$ & $-.23^{* *}$ & $-.20 * *$ & $-.15^{* *}$ & $.37^{* *}$ & $-.19 * *$ \\
\hline $\begin{array}{l}\text { Search for } \\
\text { Attention }\end{array}$ & $-.17^{* *}$ & $-.23 * *$ & $-.17 * *$ & $-.09 * *$ & -.03 & $.25^{* *}$ & $-.17^{* *}$ \\
\hline $\begin{array}{l}\text { Interpersonal } \\
\text { Superficiality }\end{array}$ & .06 & $.12 * *$ & $.18 * *$ & .06 & $.22 * *$ & -.06 & $.09 *$ \\
\hline \multicolumn{8}{|l|}{$\begin{array}{l}\text { IDCP-2 - } \\
\text { Grandiosity }\end{array}$} \\
\hline $\begin{array}{l}\text { Need for } \\
\text { Recognition }\end{array}$ & $-.16 * *$ & $-.24^{* *}$ & $-.29 * *$ & $-.20 * *$ & .01 & $.16 * *$ & $-.20 * *$ \\
\hline Superiority & -.01 & .06 & $-.11 * *$ & .01 & $.19 * *$ & -.03 & .06 \\
\hline Dominance & .03 & $.15^{* *}$ & $.08 *$ & $.11^{* *}$ & $.28 * *$ & $-.12 * *$ & $.14^{* *}$ \\
\hline Indifference & $-.11 * *$ & $-.16 * *$ & $-.21 * *$ & $-.13^{* *}$ & $-.11 * *$ & $.11^{* *}$ & $-.14^{* *}$ \\
\hline \multicolumn{8}{|l|}{$\begin{array}{l}\text { IDCP-2 - } \\
\text { Inconsequence }\end{array}$} \\
\hline Impulsiveness & $-.23^{* *}$ & $-.30 * *$ & $-.15^{* *}$ & $-.18 * *$ & $-.16 * *$ & $.27^{* *}$ & $-.23 * *$ \\
\hline Risk Taking & -.03 & .02 & -.03 & -.02 & $.10^{*}$ & .01 & -.02 \\
\hline Deceitfulness & $-.07^{*}$ & $-.09 * *$ & $-.13^{* *}$ & -.01 & .02 & .07 & $-.11 * *$ \\
\hline \multicolumn{8}{|l|}{$\begin{array}{l}\text { IDCP-2 } \\
\text { - Conscienti- } \\
\text { ousness }\end{array}$} \\
\hline $\begin{array}{l}\text { Need for } \\
\text { Routine }\end{array}$ & $-.29 * *$ & $-.36 * *$ & $-.27^{* *}$ & $-.19 * *$ & $-.28 * *$ & $.33^{* *}$ & $-.20 * *$ \\
\hline $\begin{array}{l}\text { Concern with } \\
\text { Details }\end{array}$ & $-.17^{* *}$ & $-.20 * *$ & $-.13 * *$ & $-.17 * *$ & .01 & $.26 * *$ & $-.12 * *$ \\
\hline Thoroughness & $.07^{*}$ & .02 & -.04 & -.02 & $.13^{* *}$ & .02 & .07 \\
\hline Workaholic & $-.10 * *$ & $-.13^{* *}$ & $-.16 * *$ & $-.11 * *$ & -.04 & $.12^{* *}$ & $-.09^{*}$ \\
\hline $\begin{array}{l}\text { Self-directed } \\
\text { Perfectionism }\end{array}$ & $-.15^{* *}$ & $-.19 * *$ & $-.19 * *$ & $-.15^{* *}$ & $-.10^{*}$ & $.16 * *$ & $-.15^{* *}$ \\
\hline $\begin{array}{l}\text { Emotional } \\
\text { Constriction }\end{array}$ & -.01 & $-.07^{*}$ & $-.20 * *$ & $-.07^{*}$ & -.07 & $.12 * *$ & $-.12 * *$ \\
\hline
\end{tabular}

Note: Effect size expressive from .17 (using power $\geq .80, N=275, \mathrm{p} \leq .05$ ), calculated in G*Power 3 and based on Hemphill (2003).

$* \mathrm{p}<=.05, * * \mathrm{p}<=.01$ 
It is possible to notice that some of the factors correlate expressively with quality of life (e.g., Emotional Intensity, Impulsiveness, and Need for Routine), while other factors still displayed low correlations. Most of it was significant, from positive and negative .07 (WHOQOL physical domain with Deceitfulness and Thoroughness; WHOQOL psychological domain with Emotional constriction) to .37 (PANAS- with Emotional Intensity).

While the correlations analyses allow the investigation of each IDCP-2 variables relationship with quality of life measures, we also conducted logistic regression analysis predicting groups based on clinical sociodemographic variables, and multiple linear regression analyzes predicting groups based on life satisfaction, positive affects, and quality of life. Table 3.3 presents the results. Collinearity diagnosis based on tolerance and VID showed no need for variables exclusion. Controlling for gender and age was not significant in the model, i.e., it did not predict quality of life. For the clinical sociodemographic variable, r2Nagelkerke was .39, predicted by Mood Instability, Eccentricity, and Conscientiousness, with the latter associating negatively. For Life Satisfaction, r2Nagelkerke was .27, predicted by Self-sacrifice, Isolation, and Conscientiousness, with the latter associating positively. For PANAS positive affects, r2Nagelkerke was .32, negatively predicted by Criticism Avoidance, Dependency, Isolation, and Self-sacrifice, and positively by Grandiosity, Conscientiousness, and Attention Seeking. For the general life quality (sum of WHOQOL scores), r2Nagelkerke was .48, predicted negatively by Mood Instability, Self-sacrifice, Criticism Avoidance, and Isolation, and positively by Conscientiousness and Attention Seeking.

Table 3.3. Multiple and logistic regression analyses predicting four variables from IDCP-2 domains $(N=1618)$.

\begin{tabular}{lccccc}
\hline & B & S.E. & Wald & df & Sig. \\
\hline $\begin{array}{l}\text { Clinical } \\
\text { sociodemographic }\end{array}$ & & & & & \\
\hline Mood Instability & 3.065 & .389 & 62.054 & 1 & $<.001$ \\
\hline Eccentricity & .958 & .401 & 5.717 & 1 & .017 \\
\hline Conscientiousness & -1.281 & .445 & 8.286 & 1 & .004 \\
\hline Life satisfaction & & & & & \\
\hline
\end{tabular}


Table 3.3. Multiple and logistic regression analyses predicting four variables from IDCP-2 domains $(N=1618)$. (conclusion)

\begin{tabular}{lccccc}
\hline & B & S.E. & Wald & df & Sig. \\
\hline Self-sacrifice & -.467 & .393 & -- & -- & $<.001$ \\
\hline Isolation & -.196 & .496 & -- & -- & $<.001$ \\
\hline Conscientiousness & .098 & .645 & -- & -- & .016 \\
\hline PANAS+ & & & & & \\
\hline Criticism Avoidance & -.237 & .641 & -- & -- & $<.001$ \\
\hline Grandiosity & .135 & .590 & -- & -- & .006 \\
\hline Self-sacrifice & -.155 & .632 & -- & -- & .008 \\
\hline Isolation & -.184 & .621 & -- & -- & $<.001$ \\
\hline Conscientiousness & .130 & .671 & -- & -- & .003 \\
\hline Dependency & -.187 & .652 & -- & -- & .002 \\
\hline Attention Seeking & .126 & .514 & -- & -- & .004 \\
\hline Life quality & & & & -04 & $<.001$ \\
\hline Mood Instability & -.365 & .671 & -- & -- & $<.001$ \\
\hline Criticism Avoidance & -.181 & .706 & -- & -- & $<.001$ \\
\hline Self-sacrifice & -.244 & .568 & -- & -- & $<.001$ \\
\hline Attention Seeking & .089 & .442 & -- & -- & -001 \\
\hline Conscientiousness & .118 & .662 & -- & -- & $<$ \\
\hline Isolation & -.118 & .607 & -- & -- & $<$ \\
\hline
\end{tabular}

To illustrate the relation between the twelve IDCP-2 domains and the four predicted life quality variables, we generated graphs for the two groups. Figure 3.1 presents the graphs.

According to what was observed in the tables, in almost all the cases the clinical group presented a higher score in comparison to the non-clinical group. Higher discrepancies were observed for clinical sociodemographic comparisons. 

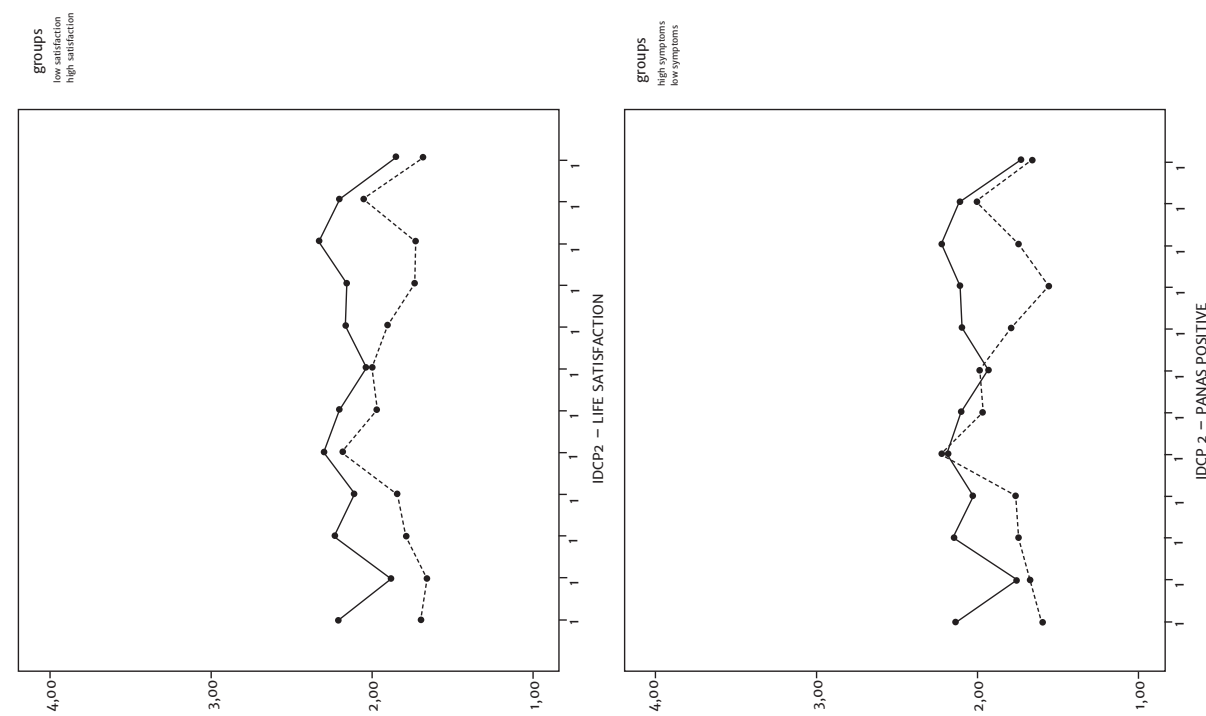

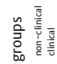
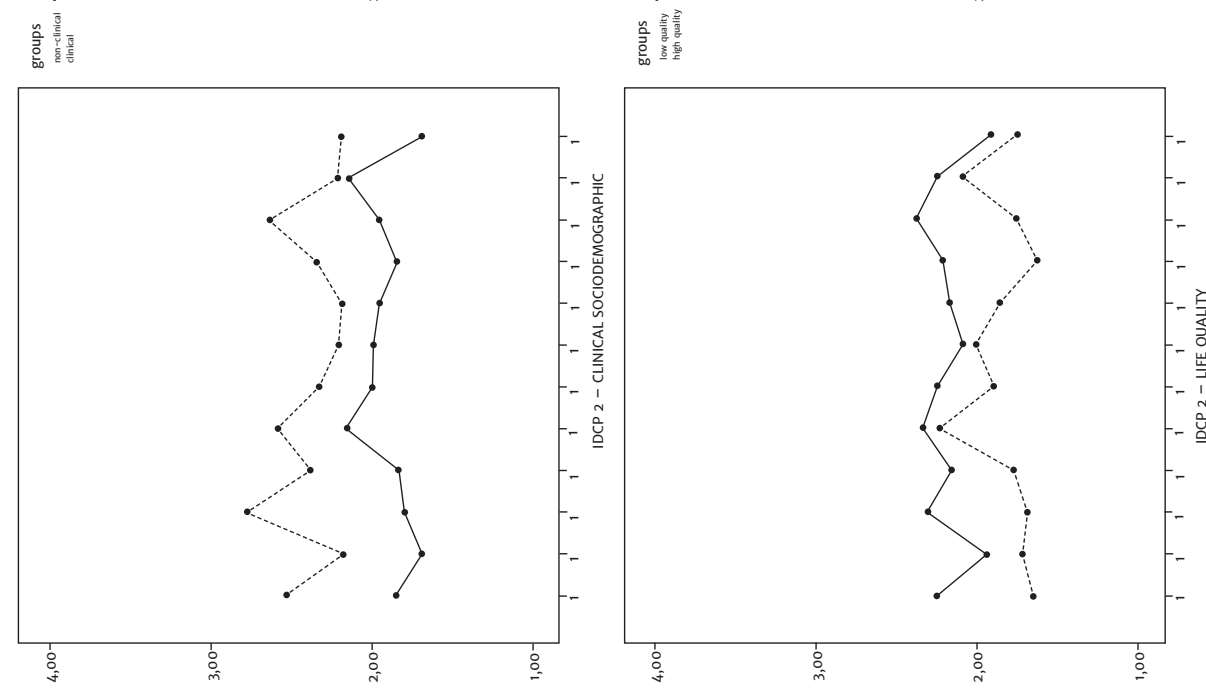


\section{Discussion}

As argued in the present study, measures assessing pathological traits of personality are expected to discriminate people with high and low indicators of quality of life. Based on that, we tested the discriminative capacity of the IDCP-2 (Carvalho \& Primi, 2018). As hypothesized (Cloninger \& Zohar, 2011; Farrand \& Woodford, 2013; Huang et al., 2017; Narud, Mykletun, \& Dahl, 2005), the general trends were negative correlations between the dimensions of IDCP- 2 with most factors from the other measures, as they evaluate positive attributes (i.e., life satisfaction, quality of life and positive experience of affects). The exception, albeit still coherent considering the constructs implicated, was the positive association between personality and PANAS-, an indicator of negative affects (Giacomoni \& Hutz, 1997). These results directly indicate validity evidences for the IDCP-2 dimensions, as a high correlation in this measure should represent low levels of quality of life, life satisfaction, and positive affects. Moreover, findings observed for correlations were consistent with those found in regression analyses and group comparisons. Accordingly, IDCP-2 could be used as an indicator of the absence or the lack of these positive outcomes. Mostly, we found that presenting high scores on Mood Instability, Self-sacrifice and Isolation (and to a lesser degree, Criticism Avoidance) and low scores on Conscientiousness (and to a lesser degree, Attention Seeking), is an indicative of poor quality of life, as it is discussed in the next paragraphs.

Regarding the correlations, attending to the effect size cutoff criteria (i.e., r $\geq .17$ ), the highest effects from the quality of life measure (WHOQOL-bref) were observed for the psychological factor, correlating mainly with Mood Instability, Self-sacrifice, Dependency, and Criticism Avoidance. Probably these correlations are explained by the internalizing aspect (Kotov et al., 2017) as a common ground underlying these indicators. The same can be hypothesized for PANAS and Life Satisfaction measures, as they seem to be more related to aspects of the self than relational attributes, and similar patterns of correlations were also observed in this research.

Only two dimensions of IDCP-2 did not correlate with the other measures, Grandiosity and Inconsequence, with Attention Seeking showing one expressive correlation (i.e., PANAS-). Maybe the explanation for Grandiosity and Attention Seeking dimensions is the same, as both are related to need to be admired (Carva- 
Iho, Sette, Capitão, \& Primi, 2014; Hemphill, 2003), which also applies to the narcissistic personality disorder and histrionic personality disorder (American Psychiatric Association, 2013), the most related personality disorders in these dimensions. In general, the symptoms related to these pathological personality patterns are assessed through their social relationships, as seduction, manipulation, and dominance (American Psychiatric Association, 2013; Millon, 2011). As the measures we administered are more related to self-attributes and less to social relationships, maybe the effect sizes tend to be low, reflecting the small correspondence between these patterns and psychological positive attributes mainly associated with the self. Corroborating this hypothesis, in Table 3.2 we found the social factor from quality of life measure showing significant correlations with Grandiosity and Attention Seeking dimensions.

Moreover, concerning the Inconsequence dimension, the correlations on factor levels showed the Impulsiveness factor as the one with the highest correlations with the positive measures, and also with the negative one (i.e., PANAS-). The impulsivity trait of personality is recognized to bring substantial decrease in the quality of life, especially as part of a personality disorder, as borderline or antisocial (Carvalho, Sette, \& Ferrari, 2016; Millon \& Grossman, 2007a, 2007b). The other two factors, Risk Taking and Deceitfulness, did not imply a decrease in the quality of life or life satisfaction, which leads to the conclusive that a high score in Inconsequence is not related to high scores in these two traits.

Analyzing the results from the regression analyzes, the IDCP- 2 best performance was predicting the groups according to quality of life, probably because the WHOQOL is composed by several factors (The WHOQOL Group, 1998), encompassing more information in comparison to the other measures. Moreover, the clinical sociodemographic variable showed the second highest effect size in prediction, which is desirable in terms of validity evidence (Paris, Chenard-Poirier, \& Baskin, 2013), as psychological tests should be able to predict robust external criteria. The graphics in Figure 3.1 corroborate the regression analyzes, as the so-called clinical groups (i.e., the lowest scores in the measures, and affirmative for at least one of the clinical questions) usually presented high scores in IDCP-2 dimensions. Specifically, almost all IDCP-2 dimensions appeared as significant predictors of some of the variables, with the exceptions of Aggressiveness and Inconsequence. As we observed before, two of the three Inconsequence factors were not related to the 
positive measures or even the negative one (i.e., PANAS-), so we could not expect this dimension as a good predictor for this variables in the present sample. Both, Aggressiveness and Inconsequence have a common ground related to risk behaviors, more related to violence and antagonism for Aggressiveness, and more related to drug use, unprotected sex behavior, etc. for Inconsequence. These behaviors seem to be less frequently reported, as the mean for these dimensions were the lowest (i.e., $M=1.8$ and $M=1.8$ versus a range from 2.02 for Eccentricity to 2.32 for Attention Seeking), which could explain why they do not significantly cooperate in predicting the variables.

According to previous studies (Carvalho, Pianowski, \& Reis, 2017), we could expect the Mood Instability and Eccentricity domains as substantial predictors, mainly the Mood Instability, as this trait seems to be one of the personality disorders' core (Carvalho, 2017). Regarding the Eccentricity dimension, the contribution of this dimension is not clear, as it comprises characteristics that are more common to the schizotypal and schizoid personality disorders (Patel et al., 2015), comprising interpersonal detachment and eccentric perception/behavior. We suggest further investigations on the role of this dimension as a common component of the pathological personality manifestations in the different personality disorders.

Furthermore, in the three cases in which Conscientiousness was sustained in the regression model, its direction was contrary to other dimensions, such as Mood Instability and Eccentricity, and was in the same direction as Attention Seeking. This pattern, only observed in the models considering several traits at the same time (but not observed in one by one correlations), can occur as an effect related to the measurement of pathological traits, mainly Conscientiousness and Attention Seeking, as discussed previously in literature (Carvalho, Pianowski, Silveira, Bacciotti, \& Vieira, 2016; Carvalho, Souza, \& Primi, 2014). Indeed, these pathological traits tend to seem less impaired in comparison to other pathological traits. The Conscientiousness and Attention Seeking dimensions composing the IDCP-2 were revised in order to not present this issue (Carvalho, Sette et al., 2014; Carvalho, Souza et al., 2014), but future studies should focus on verifying whether it is still occurring or not.

In the search for understanding these results, we also proceed to correlations between Conscientiousness factors and Attention Seeking factors (Table 3.2). Need for Routine was the IDCP-2 factor from Conscientiousness that presented the 
highest correlations with the other measures, all of them above .17. However, the other factors showed poor correlations. Need for Routine is related to a clear preference for regularity in daily life, without changes in habits. It is related to what Millon (2011) called adaptive inflexibility, one of the main aspects of personality disorders, i.e., the tendency to neglect alternative strategies to achieve goals. Something similar was observed for Attention Seeking factors, as Emotional Intensity showed the highest correlations followed by Search for Attention, while the others did not correlate in general. Future studies should verify if the same pattern observed in the present work is replicated.

Similar to Conscientiousness and Attention Seeking, the Grandiosity dimension also presented an unexpected pattern in the prediction of PANAS+, showing an opposite direction in relation to the other personality dimensions. Although not expected, traits encompassed by the Grandiosity dimension (e.g., need for recognition) are closely related to traits from the Attention Seeking dimension (e.g., search for attention). Moreover, traits from these dimensions share a higher latent construct (Kotov et al., 2017), and they are also linked as criteria for narcissistic and histrionic personality disorders (APA, 2013). Studies trying to replicate the present findings should take into consideration the associations between traits from Grandiosity and Attention Seeking dimensions.

The generalizability of the results should be weighted according to the main limitations of the research. All measures were based on self-report and all measures were administered only once, thus the risk of the results being influenced by the common method bias is substantial. Furthermore, the measures were administered only in the general population, thus maybe the observed patterns could change at some level in samples composed mainly by psychiatric patients, specifically those presenting personality disorders diagnoses, considering the nature of IDCP-2.

\section{References}

Acquadro, C., Conway, K., Hareendran, A., \& Aaronson, N. (2008). Literature review of methods to translate health-related quality of life questionnaires for use in multinational clinical trials. Value in Health, 11(3), 509-521. doi:10.1111/j.1524-4733.2007.00292.x 
Anderson, J. L., \& Sellbom, M. (2018). Evaluating the DSM-5 Section III personality disorder impairment criteria. Personality Disorders: Theory, Research, and Treatment, Online First Publication, 9(1), 51-61. doi:10.1037/perooo0217

American Psychiatric Association (2013). Diagnostic and Statistical Manual of Mental Disorders, Fifth Edition (DSM-5). Arlington: American Psychiatric Publishing.

Brief, A. P., Butcher, A. H., George, J. M., \& Link, K. E. (1993). Integrating bottom-up and top-down theories of subjective well-being: The case of health. Journal of Personality and Social Psychology, 64(4), 646-653.

Brunault, P., Champagne, A.-L., Huguet, G., Suzanne, I., Senon, J.-L., Body, G., ... Camus, V. (2016). Major depressive disorder, personality disorders, and coping strategies are independent risk factors for lower quality of life in non-metastatic breast cancer patients: Psychological risk factors for lower quality of life after breast cancer. Psycho-Oncology, 25(5), 513-520. doi:10.1002/pon.3947

Carvalho, L. F. (2017). External validity study of a personality disorders screening in a community sample. Archives of Clinical Psychiatry (São Paulo), 44, 40-44.

Carvalho, L. F., Pianowski, G., \& Reis, A. M. (2017). Development and diagnostic accuracy of the screening of the Dimensional Clinical Personality Inventory. Psicologia: Ciência e Profissão, 37(4), 1011-1024. doi:10.1590/1982-3703003082016

Carvalho, L. F., Pianowski, G., Silveira, F. J., Bacciotti, J. T., \& Vieira, P. G. (2016). Eccentricity dimension of the Dimensional Clinical Personality Inventory: Review and psychometric properties. Estudos de Psicologia, 21(4), 359-368. doi:10.5935/1678-4669.20160035

Carvalho, L. F., \& Primi, R. (2015). Development and internal structure investigation of the Dimensional Clinical Personality Inventory. Psicologia: Reflexão e Crítica, 28(2), 322-330. doi:10.1590/1678-7153.201528212

Carvalho, L. F., \& Primi, R. (2018). Inventário Dimensional Clínico da Personalidade 2 (IDCP2) e Inventário Dimensional Clínico da Personalidade - versão triagem (IDCP-triagem). São Paulo: Pearson.

Carvalho, L. F., \& Sette, C. P. (2017). Revision of the Criticism Avoidance dimension of the Dimensional Clinical Personality Inventory. Estudos de Psicologia (Campinas), $34,219-231$.

Carvalho, L. F., Sette, C. P., Capitão, C. G., \& Primi, R. (2014). Propriedades psicométricas da versão revisada da dimensão Necessidade de Atenção do Inventário Dimensional Clínico da Personalidade. Temas em Psicologia, 22, 147-160. 
Carvalho, L. F., Sette, C. P., \& Ferrari, B. L. (2016). Revision of the grandiosity dimension of the Dimensional Clinical Personality Inventory and verification of its psychometric properties. Trends in Psychiatry and Psychotherapy, 1, 1-9.

Carvalho, L. F., \& Silva, G. F. C. (2016). Review of the Self-sacrifice Dimension of the Clinical Dimensional Personality Inventory. Psicologia: Reflexão e Crítica, 29(6), 1-8. doi:10.1186/s41155-016-0022-z

Carvalho, L. F., Souza, B. D. B., \& Primi, R. (2014). Psychometric properties of the revised conscientiousness dimension of Inventário Dimensional Clínico da Personalidade (IDCP). Trends in Psychiatry and Psychotherapy, 36, 23-31.

Cella, D. F. (1994). Quality of life: Concepts and definition. Journal of Pain and Symptom Management, 9(3), 186-192. doi:10.1016/0885-3924(94)90129-5

Cloninger, C. R., \& Zohar, A. H. (2011). Personality and the perception of health and happiness. Journal of Affective Disorders, 128, 24-31. doi:10.1016/j.jad.2010.06.012

Cramer, V., Torgersen, S., \& Kringlen, E. (2006). Personality disorders and quality of life. A population study. Comprehensive Psychiatry, 47, 178-184. doi:10.1016/j. comppsych.2005.06.002

Diener, E., Emmons, R. A., Larsen, R. J., \& Griffin, S. (1985). The Satisfaction with Life Scale. Journal of Personality Assessment, 49(1), 71-75. doi:10.1207/s15327752jpa4901_13

Farquhar, M. (1995). Definitions of quality of life: A taxonomy. Journal of Advanced Nursing, 22(3), 502-508. doi:10.1046/j.1365-2648.1995.22030502.x

Farrand, P., \& Woodford, J. (2013). Measurement of individualised quality of life amongst young people with indicated personality disorder during emerging adulthood using the SEIQoL-DW. Quality of Life Research, 22, 829-838. doi:10.1007/ s11136-012-0210-y

Felce, D., \& Perry, J. (1995). Quality of life: Its definition and measurement. Research in Developmental Disabilities, 16(1), 51-74. doi:10.1016/0891-4222(94)00028-8

Fleck, M. P., Louzada, S., Xavier, M., Chachamovich, E., Vieira, G., Santos, L., \& Pinzon, V. (2000). Aplicação da versão em português do instrumento abreviado de avaliação da qualidade de vida "WHOQOL-bref." Revista de Saúde Púlbica, 34(2). doi:10.1590/ So034-89102000000200012

Giacomoni, C. H., \& Hutz, C. S. (1997). A mensuração do bem-estar subjetivo: Escala de afeto positivo e negativo e escala de satisfação de vida. In Interamerican Society of 
Psychology (Ed.), Proceedings of the XXVI Interamerican Congress of Psychology (p. 313). São Paulo: IPS.

Hemphill, J. F. (2003). Interpreting the magnitudes of correlation coefficients. American Psychologist, 58(1), 78-79. doi:10.1037/0003-066X.58.1.78

Huang, I.-C., Lee, J. L., Ketheeswaran, P., Jones, C. M., Revicki, D. A., \& Wu, A. W. (2017). Does personality affect helath-related quality of life? A systematic review. PLoS ONE, 12(3). Doi:10.1371/journal.pone.0173806

Karimi, M., \& Brazier, J. (2016). Health, Health-Related Quality of Life, and Quality of Life: What is the difference? PharmacoEconomics, 34(7), 645-649. doi:10.1007/ s40273-016-0389-9

Kotov, R., Krueger, R. F., Watson, D., Achenbach, T. M., Althoff, R. R., Bagby, R. M., ... Wright, A. G. C. (2017). The Hierarchical Taxonomy of Psychopathology (HiTOP): A Dimensional Alternative to Traditional Nosologies. Journal of Abnormal Psychology, 126(4), 454-477. doi:10.1037/abnoooo258

Krueger, R. F., Derringer, J., Markon, K. E., Watson, D., \& Skodol, A. E. (2012). Initial construction of a maladaptive personality trait model and inventory for DSM-5. Psychological Medicine, 42(9), 1879-1890. doi:10.1017/S003329171100267

Manning, N. (2000). Psychiatric diagnosis under conditions of uncertainty: Personality disorder, science and professional legitimacy. Sociology of Health \& IIIness, 22(5), 621-639. doi:10.1111/1467-9566.00223

Millon, T. (2011). Disorders of personality: Introducing a DSM/ICD spectrum from normal to abnormal. New Jersey: John Wiley \& Sons.

Millon, T., \& Grossman, S. (2007a). Moderating severe personality disorders. New Jersey: John Wiley \& Sons.

Millon, T., \& Grossman, S. (2007b). Overcoming resistant personality disorders. New Jersey: John Wiley \& Sons.

Narud, K., Mykletun, A., \& Dahl, A. A. (2005). Quality of life in patients with personality disorders seen at an ordinary psychiatric outpatient clinic. BMC Psychiatry, 5(10). doi:10.1186/1471-244X-5-10

Paris, J., Chenard-Poirier, M., \& Baskin, R. (2013). Antisocial and borderline personality disorders revisited. Comprehensive Psychiatry, 54, 321-325. 
Patel, R., Lloyd, T., Jackson, R., Ball, M., Shetty, H., Broadbent, M., \& Taylor, M. (2015). Mood instability is a common feature of mental health disorders and is associated with poor clinical outcomes. BMJ Open, 5.

The WHOQOL Group (1998). Development of the World Health Organization WHOQOL-BREF Quality of life assessment. Psychological Medicine, 28(3), 551-558.

Watson, D., Clark, L. A., \& Tellegen, A. (1988). Development and validation of brief measures of positive and negative affect: The PANAS scales. Journal of Personality and Social Psychology, 54(6), 1063-1070. doi:10.1037/0022-3514.54.6.1063

Wilson, W. R. (1967). Correlates of avowed happiness. Psychological Bulletin, 67(4), 294-306. Zanon, C., Bardagi, M. P., Layous, K., \& Hutz, C. S. (2014). Validation of the Satisfaction with Life Scale to Brazilians: Evidences of measurement noninvariance across Brazil and US. Social Indicators Research, 119(1), 443-453. doi:10.1007/s11205-013-0478-5

\section{Authors notes}

Lucas de Francisco Carvalho, Department of Psychology, São Francisco University (USF); Ana Carolina Zuanazzi, Department of Psychology, São Francisco University (USF); Fabiano K. Miguel, Department of Psychology and Psychoanalysis, State University of Londrina (UEL).

Correspondence concerning this article should be addressed to Lucas de Francisco Carvalho, Universidade São Francisco, Department of Psychology and Psychoanalysis,, Rua Alexandre Rodrigues Barbosa, 45, Centro, Itatiba, São Paulo, Brazil. CEP 13251-900. E-mail: lucas@labape.com.br 